\title{
Metaphor in Mark Forster's Album LIEBE S/W
}

\author{
Muhammad Reza \\ Department of Linguistics, Universitas Pendidikan Indonesia \\ rezamuhammadwu@upi.edu
}

\begin{abstract}
This study is a cognitive semantic analysis of the conceptual metaphor of the song lyrics in Mark Forster's album Liebe S/W. The method used is descriptive qualitative. The theories used are the conceptual metaphor theory (CMT) by Lakoff\&Johnson (2003) as the main theory and image schema theory by Croft \& Cruse (2004). The data sources in this study were taken from the lyrics of 14 German songs from the album Liebe S/W (2019) by Mark Forster. This study was carried out for the purpose of describing the characteristics of the metaphors, the types of conceptual metaphors and image schemes contained in the song lyrics in the album. Mark Forster's cognition as a singer-songwriter on the album can be seen with this study through a conceptual metaphor approach. Based on the results of the research, it is found as many as 52 data containing metaphorical expressions. Based on the analysis in accordance with Saeed's theory as a metaphor characteristic theory, it shows that there are 13 data with abstraction, 15 data with conventionality, 9 data with systematicity, and 15 data with asymmetry. The ontological metaphors is the most dominant in the album. Data analysis using the Lakoff\&Johnson theory shows that the conceptual metaphors are found as many as 32 ontological metaphors, 15 orientational metaphors, and 5 structural metaphors. The image schemes found are 20 containers, 4 multiplicities, 4 existences, 5 identites, 12 spaces and 1 scale. Some patterns were found based on theories, 1) metaphors with the characteristics of abstraction and asymmetry have ontological, orientational and structural conceptual metaphors with all types of image schemes. 2) metaphors with conventional characteristics only have ontological conceptual metaphor type with some image schemes, except multiplicity. 3) metaphors with systematic characteristics have ontological and orientation conceptual metaphors with image schemes, except identity and scale.
\end{abstract}

Keywords

conceptual metaphor, cognitive semantics, song lyrics, mark forster's albumLiebe SN

\section{Introduction}

Language can be interpreted as a symbol of sound in essence that humans use to communicate with one another. Along with the times, the creative way for humans to process language is to make songs, musical poetry, rhymes, and others. One of the human creativities with language as a very prominent medium is in the field of singing or what is also known as music. One of the creativity in the field of singing is writing song lyrics which are written by songwriters. The song is a work of art in relation to sound art and language art, as a sound artwork involving the melody and the voice of the singer (Djohan, 2016: 8). Songs are also works of art that combine sound art and poetic art in which they contain meaning that expresses their experiences or whatever they are feeling so that they can make the listener feel the emotions contained in them. Songs have various themes, it is ranging from themes of life, politics, friendship, love, and so on. 
Metaphors play an important role in human thought and also in the creation of social, cultural, and psychological reality (Moradi \& Jabbari, 2020). Metaphorical expressions, as the second factor, mean any constructions evoking visual, sounds, touch, and taste images, the traditional metaphors, direct comparisons without the words " like" and "as if", and all figurative languages (Noie, 2018). As a vehicle for expressing emotions and feelings and to be beautiful to hear, songs contain many metaphorical expressions. In the traditional view, the meaning contained in a metaphor belongs to the semantic field which focuses on the relationship between the linguistic unit and its meaning. Semantics is a study of meaning that is contained in human language (Saifullah, 2018: 1). However, currently in its development, there is a new view in seeing the relationship between the linguistic unit and its meaning, namely the cognitive semantic field. This field focuses on the relationship between linguistic units, meaning, and cognition. The linguistic unit is seen as a symbol that is closely related to mental representations called concepts, this concept is related to perceptual problems. For example, when a person sees a fish that resembles a shark, in his mind he carries out a process of perceiving the physical form of the animal, such as its shape, size, sound, smell, and behavior. It can be interpreted that cognitive linguistics is how a person uses language, and then conceptualizes the language, understands, and then responds to the available language.

The ability of human perception is closely related to the problem of external and abstract concepts, which means that new humans can make perceptions when a real phenomenon can be captured by the senses. Many things can be researched in the field of cognitive linguistics, one of which is conceptual metaphors.

\section{a. YOU ARE MY SUNSHINE}

In sentence above, the word you is the tenor (the element that is explained), while my sunshine is the vehicle (the element that explains). The word you is juxtaposed with sunshine which describes you as a person who seems to have the inherent characteristics of sunlight. The definition of the word sunshine is direct sunlight unbroken by cloud, especially over a comparatively large area (Online Oxford Dictionary). The literal meaning of the word sunshine is direct sunlight that is not obstructed by clouds. This sunlight is a light that radiates, illuminates the universe, gives warmth and life to creatures in the world. 'You' here has a metaphorical meaning, which means that the figure of you can give light to someone's life, so that someone feels that his life is more radiant and more colorful. However, the determination of the nature or characteristics of a form transferred to another form is not arbitrary but based on human experience. Transferring the characteristics or nature of a certain thing to another requires broad and general knowledge in the culture of speakers is by considering the similarity of the background knowledge of the speakers so that the message in the concept expressed can be understood. Lakoff and Johnson (2003: 45) provide examples of conceptual metaphors as follows:

b. LOVE IS JOURNEY

Love is the realm of the target while Journey is the realm of the source, the explanation of the metaphorical expression is as follows:

- Look how far we've come.

- We're at a crossroads.

- We 'll just have to go our separate ways. We can't turn hack now. I don't think this relationship is going anywhere.

Lakoff and Johnson emphasized that the above metaphorical expressions are not the eleven conceptual metaphors. They are descriptions of the LOVE IS JOURNEY conceptual metaphor. Based on the above metaphorical expressions, Lakoff and Johnson provide an explanation that Love as the target domain (the domain that is described) is 
conventionally structured in the term Journey as the source domain (the domain that describes the target realm). There is a cognitive view that can reveal a metaphorical form, namely the view according to Saeed (2009) which states that metaphors have 4 characteristics, namely conventionality, systematicity, assymetry and abstraction.

1) Conventionality is a general metaphor so that its existence has been considered as everyday vocabulary used by society (dead metaphor). This feature is a new metaphor that is accepted by speakers, which is related to the novelty of the ideas that are in it. In the cognitive semantic approach, this feature becomes a tool to refute the notion of the concept of "dead metaphors", namely metaphors whose meaning is no longer considered metaphorical due to continuous use.

2) Systematicity means that there is a comparison between the source domains and the target domains which are grouped in the point of similarity. This feature relates not only to the way the metaphor takes a point of comparison between the source and target realms, but also to how the metaphor builds a logical framework for itself.

3) Asymmetry, which is comparing two unidirectional concepts. This feature means that the metaphor compares two concepts from one direction, namely from the source realm to the target realm and the comparisons are not comparable. Metaphors only encourage the listener to attach a source's trait to the target.

4) Abstraction, metaphor tries to transfer the inherent nature of something more concrete to something more abstract.

Furthermore, to analyze metaphors, researcher used conceptual metaphor theory (Lakoff \& Johnson, 2003). Conceptual metaphors consist of three types, namely structural metaphors, orientational metaphors, and ontological metaphors.

1) Structural metaphor, which is a concept formed metaphorically by using another concept. This structural metaphor is based on two domains, namely the realm of the source and the realm of the target. Structural metaphors are based on systematic correlations in everyday experience.

2) Orientational metaphors are metaphors related to spatial orientation, such as up and down, inside-outside, front-back, and others. This spatial orientation arises from the fact that we have bodies and bodies function in a physical environment. This metaphor is based more on human physical experience in regulating the orientation of the direction in everyday life, such as "UPDOWN" which is measured from human physical experience. Orientational metaphors reflect different spatial concepts according to the physical experience or culture of the people. Therefore, orientational metaphors differ in each culture, because of what someone who grew up in a different culture thought, experienced, did. Orientational metaphors provide a concept of a spatial orientation, for example: HAPPY IS UP, HEALTH IS UP.

3) Ontological metaphors are metaphors that see events, emotional activities, and ideas as entities and substances. For example in the metaphor "THE MIND IS A MACHINE" in the sentence "My mind just isn't operating today" (today my brain is not working or today I don't want to think). Ontological metaphors are metaphors that conceptualize thoughts, experiences, and processes of abstract things into something that has a physical nature. In other words, the ontological metaphor describes an abstract goal into something concrete. Ontological metaphors are used to comprehend events, actions, activities, and states. Events and actions are conceptualized metaphorically as objects, activities as sub-stances, states as containers. A race, for example, is an event, which is viewed as a discrete entity. The race exists in space and time, and it has well-defined boundaries (Lakoff \& Johnson, 2003: 35) [7]. 
Apart from the types of conceptual metaphors, there are also image schemes that are formed from a metaphor. Image schemas are an important form of conceptual structure in cognitive semantic literature. The basic idea is that because of our physical experience of being and acting in the world - of perceiving the environment, moving our bodies, exerting and experiencing force, etc we form basic conceptual structures which we then use to organize thought across a range of more abstract domains (Saeed, 2003: 353) [8]. Image schematic according to Croft \& Cruse $(2004,45)$ [17] which is divided into seven parts which can be seen in the following table:

Table 1. Image Scheme by Cruse and Croft (2004)

\begin{tabular}{|c|c|}
\hline \multicolumn{2}{|c|}{ Image scheme by Cruse and Croft (2004) } \\
\hline Space & $\begin{array}{l}\text { Up-Down, Front-Back, Left-Right, Near-far, } \\
\text { CenterPeriphery, Contact }\end{array}$ \\
\hline Scale & Path \\
\hline Container & $\begin{array}{l}\text { Containment, In-Out, Surface, Full-Empty, } \\
\text { Content }\end{array}$ \\
\hline Force & $\begin{array}{l}\text { Balance, Counterforce, Compulsion, } \\
\text { Restraint, Enablement, Blockage, Diversion, } \\
\text { Attraction }\end{array}$ \\
\hline Unity/ Multiplicity & $\begin{array}{l}\text { Merging, Collection, Splitting, Iteration, } \\
\text { PartWhole, Mass-Count, Link }\end{array}$ \\
\hline Identity & Matching, Superimposition \\
\hline Excistence & $\begin{array}{l}\text { Removal, Bounded Space, Cycle, Object, } \\
\text { Process }\end{array}$ \\
\hline
\end{tabular}

The analysis of the metaphor in song lyrics has been carried out by several researchers with different approaches, including: (1) Dessiliona, Tryta \& Nur (2018) with the title Conceptual Metaphor in the Revolverheld Band Song Lyrics In Farbe album. The analysis carried out on the research data is the analysis of the conceptual metaphor types and image schemes. The method used is a qualitative description of the types of conceptual metaphors found and the image schemes contained in the data. The results of his research are in the form of conceptual metaphor types and image schema findings [16]; (2) Baiq Haula and Tajudin Nur (2018) the title Konseptualisasi Metafora dalam Rubrik Opini Kompas Tahun 2018: Kajian Semantik Kognitif. The discussion is oriented towards the study of cognitive semantics with the aim of describing the types of metaphors and image schemes. The data source in this study was taken from the Kompas opinion rubric in 2018. The method used in this study is a qualitative descriptive method, while the theory referred to in this study is cognitive semantics, relating to the types of metaphors proposed by Lakoff and Johnson (1980) and the theory of image schemes proposed by Cruse and Croft (2004). Based on the distribution of metaphor type data, ontological metaphor is the most dominant, while image schemes that are commonly found are excistence. [2]; (3) Sathyaraj Venkatesan \& Sweetha Saji (2020) with the title Reflections on the Visceral: Metaphors and Illness Experience. The research aims to provide an overview of the major theoretical postulates on metaphor, with an emphasis on Lakoff and Johnson's cognitive metaphor theory (CMT) and its correspondence to expressions of illness experience. Further, the wider implications of using metaphors, especially visual metaphors in graphic pathographies, are analysed in this research [14]. The differences between this study and some previous studies are (1) this study used the lyrics of Mark Forster's songs in Liebe's album (2) This study aims to determine the realm of sources and targets of metaphorical 
expressions contained in it, and metaphor characteristics (Saeed, 2009) [9], then this study categorized the types of conceptual metaphors. After that, this study described the conceptual metaphor mapping. and (3) this study determined the image scheme of the metaphorical expressions in the lyrics.

In this study, the writer chose Mark Forster's German lyrics of the song from the Liebe $S / W$ album as the data source. Mark Forster is a German songwriter and singer whose album contains many metaphors. The Liebe $S / W$ album was released on November 29, 2019. The album contains songs that describe Mark Forster's personal life. The album consists of 14 songs, namely (1) Comeback, (2) Einmal, (3) Liebe, (4) Was du nicht tust, (5) 194 Länder, (6) 747, (7) Danke danke, (8) Nimmerland, (9) Killer, (10) Genau wie du, (11) Chip in, (12) Irgendwann Happy, (13) Gerade Jetzt and (14) Wie früher mal dich. The research problems are (1) What are the characteristics of the metaphor in the song lyrics in Mark Forster's album Liebe $S / W$ ?, (2) What kind of conceptual metaphor is found in the song lyrics in Mark Forster's Mark Forster's album Liebe $S / W$ ? and (3) How is the image scheme contained in the song lyrics in Mark Forster's Mark Forster's album Liebe $S / W$ ?. So it can be concluded that the purpose of this study is to describe (1) the characteristics of the conceptual metaphors in Mark Forster's Mark Forster's album Liebe $S / W$, (2) the types of metaphors in Mark Forster's Mark Forster's album Liebe $S / W$, and (3) the image schemes contained on Mark Mark Forster's album Liebe $S / W$.

Theoretically, it is hoped that the conceptual metaphors in German that are discussed in this study can be a source of scientific development regarding conceptual metaphors in the study of cognitive semantics in German and linguistics in general. This research is also expected to be able to provide an explanation of the characteristics of the metaphor, the metaphorical concepts and image schemes used in the song lyrics that can be enjoyed by listeners. The practical benefit expected from this study is that it can be a reference source for anyone who wants to continue research in the same field. In addition, this research is also expected to provide information about conceptual metaphors which have been considered as one of the most widely used ways by language-users to express their emotions.

\section{Research Methods}

This study led to cognitive semantic analysis and used descriptive qualitative methods. The method used in data collection in this study is the listening method and notetaking technique. The listening method is a listening process: done by listening to the use of language (Sudaryanto, 2015: 203) [15]. This method can also be called the method of observation. After listening to the use of the language, then proceed with recording activities on the data card so that the recording becomes a data transcript that has been classified. In collecting data, this study was conducted by (1) reading song lyrics intensively, (2) understanding the meaning of each line of song lyrics using a dictionary and with the help of analyzing the meaning of the entire song lyrics (3) recording the forms of metaphorical expressions, then (4) classify the types of metaphorical expressions. The writer also considers the context which helps to understand the meaning contained in the line of the song's lyrics.

The data sources in this study were Mark Forster's songs in Liebe $S / W$ album [11] which consists of 14 songs, namely: (1) Comeback \{forty-eight lyrics\}, (2) Einmal \{fiftytwo lyrics\}, (3) Liebe \{sixty-six lyrics\}, (4) Was du nicht tust \{sixty-five lyrics\}, (5) 194 Länder \{forty-five lyrics\}, (6) 747 \{forty-seven lyrics\}, (7) Danke danke \{sixty-two lyrics\}, (8) Nimmerland \{seventy-seven lyrics\}, (9) Killer \{fifty-six lyrics\}, (10) Genau 
wie $d u$ \{forty-four lyrics\}, (11) Chip in \{seventy-four lyrics\}, (12) Irgendwann Happy \{forty-two lyrics\}, (13) Gerade jetzt \{forty-six lyrics\} and (14) Wie früher mal dich \{fortyfour lyrics $\}$. The data source is obtained from the page https://genius.com/albums/Markforster/Liebe-s-w. The data of this research are in the form of song lyrics that contain metaphors. Furthermore, as a source for determining lexical meaning in the data, the Duden dictionary - Das große Wörterbuch der deutschen Sprache (2011) [4], Duden - Das große Wörterbuch der deutschen Sprache is used online, which can be accessed via the https://www.duden.de/woerterbuch page [5], as well as the online Pons German dictionary which is accessed via the https://de.pons.com/ page [13]. The dictionaries are used by writer as reference materials to determine the basic or lexical meanings used metaphorically in the data.

After the data is collected, the data is analyzed according to the techniques of analyzing data by Miles, Huberman and Saldana (2014) [10], data analysis contains four linked processes: (1) data collection, (2) data condensation, (3) data display, and (4) conclusion drawing.

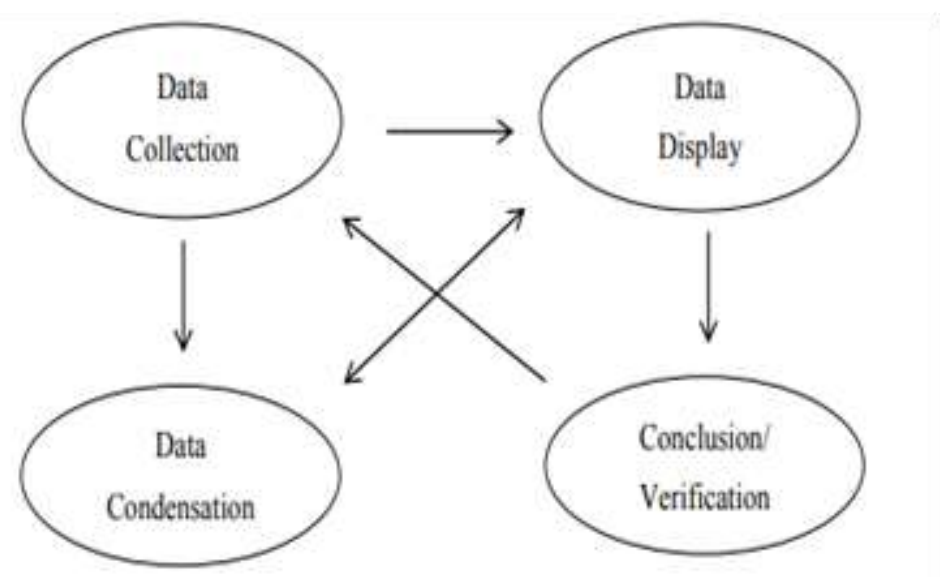

Figure 1. Interactive Model Analysis of Miles, Huberman and Saldana (2014)

1) Data Collection

Data collection refers to the process of collecting all data from Mark Forster's songs in Liebe $S / W$ album.

2) Data condensation

Data condensation consisted of the process of selecting step and focusing step. The steps of the process of data condensation can be seen as in the following:

a. Selecting Step: In this study, the first step was data selection. The data was selected by the researcher from lyrics in 14 songs of Liebe $S / W$ album. From the data selection, it can be known that metaphor in lyrics of each song.

b. Focusing Step: In focusing step, the writer focused to find out the type of conceptual metaphor based on Lakoff and Johnson (2003). Song lyrics that contained metaphorical forms are identified based on the theory by Saeed (2009) to obtain the characteristics of the metaphor. The image schemes in the songs analyzed based on theory of Cruse and Croft. Focusing step consisted of the simplifying step and abstracting step.

c. Simplifying Step: In simplified step, the writer tabulated the characteristics of the metaphor, types of conceptual metaphor with Lakoff and Johnsones theory in each song (Structural Metaphor, Orientational Metaphor, Ontological Metaphor) and image schemes in order to make easier and simple to understood. The writer did in taking of the lyrics and then giving them some codes, for bold slash lyrics are the criteria call as 
when it has found the lyric or words changes when found it of the lyrics in figurative language in each song.

d. Abstracting Step: In abstracting step, the data was abstracted by describing the tabulation of percentage each type of metaphor that was found in song lyric of Liebe $S / W$ album.

e. Transforming Step: Transforming is to describe and connect the data to the related theories.

3) Data Display

It was displayed data based on the type of conceptual metaphors from the most dominant to the last. The data was displayed on using tabulations that have columns to explain the reasons why words, phrases, or sentences in its lyrics were metaphors; named concept. The organization was explored and described into detail description in order to be easier to draw the conclusion and also to let the reader known why something in the way it is.

4) Conclusion: Drawing and Verifying

The last step was drawing conclusion. The writer interpreted the data in order to acquire the interpretation of each song and to elaborate the reason why the conceptual metaphor is used in songs lyrics of Liebe $S / W$ album from the data display. The analysis should allow the writer began to develop conclusion regarding to the study, then two objectives of the study can be verified.

\section{Results and Discussion}

The findings discuss three things related to cognitive semantics using three approaches, namely metaphor characteristics, conceptual metaphor types, and image schemes that focus on song lyrics in Mark Forster's album Liebe S/W. Metaphor analysis based on the characteristics, types of conceptual metaphors, and image schemes in the lyrics of Mark Forster's album Liebe $S / W$.

Table 2. Metaphorical analysis in Liebe $S / W$ album

\begin{tabular}{|c|c|c|c|c|}
\hline Data & Song lyrics & $\begin{array}{l}\text { Characteristics } \\
\text { of Metaphor }\end{array}$ & $\begin{array}{c}\text { Types of Conceptual } \\
\text { Metaphors }\end{array}$ & Image Scheme \\
\hline 1. & $\begin{array}{l}\text { Das Leben läuft, die Planung } \\
\text { steht } \\
\text { 'Life is on, the planning is in } \\
\text { place' } \\
\text { (Lyric in Comeback) }\end{array}$ & Conventionality & Ontological Metaphor & $\begin{array}{c}\text { Force } \\
\text { (Blockage) }\end{array}$ \\
\hline 2. & $\begin{array}{l}\text { Denk' ich zurück da an' } \\
\text { Anfang } \\
\text { 'I think back to the } \\
\text { beginning' } \\
\text { (Lyric in Comeback) }\end{array}$ & Abstraction & Orientational Metaphor & $\begin{array}{c}\text { Container } \\
\text { (In-out) }\end{array}$ \\
\hline 3. & $\begin{array}{l}\text { Ich hab' Bock aufn Comeback, } \\
\text { Baby } \\
\text { 'I'm up for a comeback baby' } \\
\text { (Lyric in Comeback) }\end{array}$ & Systematicity & Orientational Metaphor & $\begin{array}{c}\text { Space } \\
\text { (Up-down) }\end{array}$ \\
\hline 4. & $\begin{array}{l}\text { Viel zu oft war'n wir zu } \\
\text { beschäftigt } \\
\text { 'Far too often we were too } \\
\text { busy' } \\
\text { (Lyric in Comeback) }\end{array}$ & Asymmetry & Ontological Metaphor & $\begin{array}{l}\text { Container } \\
\text { (Surface) }\end{array}$ \\
\hline
\end{tabular}




\begin{tabular}{|c|c|c|c|c|}
\hline 5. & $\begin{array}{l}\text { Ne, rausreden zählt nicht 'No, } \\
\text { talking out doesn't count' } \\
\text { (Lyric in Comeback) }\end{array}$ & Systematicity & Orientational Metaphor & $\begin{array}{l}\text { Space } \\
\text { (Centre- } \\
\text { Periphery) }\end{array}$ \\
\hline 6. & $\begin{array}{l}\text { Die Nacht wird lang, viel zu } \\
\text { tun } \\
\text { 'The night will be long and } \\
\text { busy' } \\
\text { (Lyric in Comeback) }\end{array}$ & Abstraction & Structural Metaphor & $\begin{array}{l}\text { Multiplicity } \\
\text { (Link) }\end{array}$ \\
\hline 7. & $\begin{array}{l}\text { Mit Tequila-Shots drin und zu } \\
\text { dritt an die Ampel kotzten } \\
\text { 'With tequila shots in there and } \\
\text { threesome at the traffic lights } \\
\text { puked' } \\
\text { (Lyric in Einmal) }\end{array}$ & Asymmetry & Structural Metaphor & $\begin{array}{c}\text { Identity } \\
\text { (Superimposition) }\end{array}$ \\
\hline 8. & $\begin{array}{l}\text { Ich alles dreht und sich } \\
\text { verschiebt, weil's nix Größ'res } \\
\text { gibt } \\
\text { 'Everything turns and shifts } \\
\text { because there is nothing bigger' } \\
\text { (Lyric in Einmal) }\end{array}$ & Conventionality & Ontological Metaphor & $\begin{array}{c}\text { Force } \\
\text { (Restraint) }\end{array}$ \\
\hline 9. & $\begin{array}{l}\text { Doch was ich weiß, ich trag' } \\
\text { ihn für immer bei mir } \\
\text { 'But what I know, I'll carry it } \\
\text { with me forever' } \\
\text { (Lyric in Einmal) }\end{array}$ & Conventionality & Ontological Metaphor & $\begin{array}{l}\text { Container } \\
\text { (Content) }\end{array}$ \\
\hline 10. & $\begin{array}{l}\text { Und nur in mir drin kann ich } \\
\text { ihn wiederhol'n } \\
\text { 'And only inside of me can I } \\
\text { repeat it' } \\
\text { (Lyric in Einmal) }\end{array}$ & Asymmetry & Ontological Metaphor & $\begin{array}{c}\text { Container } \\
\text { (Containment) }\end{array}$ \\
\hline 11. & $\begin{array}{l}\text { Und da hilft eh nur Liebe } \\
\text { 'And then only love helps } \\
\text { anyway' } \\
\text { (Lyric in Liebe) }\end{array}$ & Abstraction & Ontological Metaphor & $\begin{array}{l}\text { Multiplicity } \\
\text { (Merging) }\end{array}$ \\
\hline 12. & $\begin{array}{l}\text { Der ganze Rest ist umsonst } \\
\text { 'All the rest is free' } \\
\text { (Lyric in Liebe) }\end{array}$ & Asymmetry & Orientational Metaphor & $\begin{array}{c}\text { Space } \\
\text { (Contact) }\end{array}$ \\
\hline 13. & $\begin{array}{l}\text { Alles okay, alles taub, alles } \\
\text { medium } \\
\text { 'Everything is okay, } \\
\text { everything is deaf, everything } \\
\text { is medium' } \\
\text { (Lyric in Was du nicht tust) }\end{array}$ & Abstraction & Structural Metaphor & $\begin{array}{c}\text { Identity } \\
\text { (Matching) }\end{array}$ \\
\hline 14. & $\begin{array}{l}\text { Blend' alles aus, dass ich ja } \\
\text { nix verpass } \\
\text { 'Hide everything so that I } \\
\text { don't miss anything' } \\
\text { (Lyric in Was du nicht tust) }\end{array}$ & Conventionality & Ontological Metaphor & $\begin{array}{l}\text { Container } \\
\text { (Content) }\end{array}$ \\
\hline 15. & $\begin{array}{l}\text { Denn mein Kopf ist bei dir } \\
\text { 'Because my head is with you' } \\
\text { (Lyric in } 194 \text { Länder) }\end{array}$ & Abstraction & Orientational Metaphor & $\begin{array}{l}\text { Space } \\
\text { (Centre- } \\
\text { Periphery) }\end{array}$ \\
\hline 16. & $\begin{array}{l}\text { Ich schick' 'n Herz in Rot zu } \\
\text { dir } \\
\text { 'I'm sending you a red heart' } \\
\text { (Lyric in } 194 \text { Länder) }\end{array}$ & Systematicity & Ontological Metaphor & $\begin{array}{c}\text { Force } \\
\text { (Attraction) }\end{array}$ \\
\hline
\end{tabular}




\begin{tabular}{|c|c|c|c|c|}
\hline 17. & $\begin{array}{l}\text { Aber dich, Baby, dich, nur } \\
\text { dich, gibt's halt einmal für } \\
\text { mich } \\
\text { 'But you, baby, you, only you, } \\
\text { there's just one time for me' } \\
\text { (Lyric in } 194 \text { Länder) }\end{array}$ & Conventionality & Ontological Metaphor & $\begin{array}{l}\text { Container } \\
\text { (Content) }\end{array}$ \\
\hline 18. & $\begin{array}{l}\text { Ich flieg' in Kreisen } \\
\text { 'I'm flying in circles' } \\
\text { (Lyric in 747) }\end{array}$ & Abstraction & Structural Metaphor & $\begin{array}{c}\text { Excistence } \\
\text { (Process) }\end{array}$ \\
\hline 19. & $\begin{array}{l}\text { Wenn ich wieder abheb' } \\
\text { 'When I take off again' } \\
\text { (Lyric in 747) }\end{array}$ & Asymmetry & Structural Metaphor & $\begin{array}{l}\text { Container (In- } \\
\text { Out) }\end{array}$ \\
\hline 20. & $\begin{array}{l}\text { Ich küss' den Boden } \\
\text { zwischendurch (ey) } \\
\text { 'I kiss the floor in between } \\
\text { (ey)' } \\
\text { (Lyric in } 747 \text { ) }\end{array}$ & Conventionality & Ontological Metaphor & $\begin{array}{c}\text { Container } \\
\text { (Containment) }\end{array}$ \\
\hline 21. & $\begin{array}{l}\text { Und ist das nicht der Sinn, zu } \\
\text { wissen, wie's schmeckt, dieses } \\
\text { Leben } \\
\text { 'And isn't that the point of } \\
\text { knowing what it tastes like, } \\
\text { this life' } \\
\text { (Lyric in 747) }\end{array}$ & Asymmetry & Ontological Metaphor & $\begin{array}{c}\text { Identity } \\
\text { (Matching) }\end{array}$ \\
\hline 22. & $\begin{array}{l}\text { Mit all sein'n hell'n und } \\
\text { dunklen Tagen } \\
\text { 'With all its light and dark } \\
\text { days' } \\
\text { (Lyric in } 747 \text { ) }\end{array}$ & Systematicity & Ontological Metaphor & $\begin{array}{l}\text { Multiplicity } \\
\text { (Collection) }\end{array}$ \\
\hline 23. & $\begin{array}{l}\text { Mit all den Orten fest im Kopf } \\
\text { dann } \\
\text { 'With all the places stuck in } \\
\text { my head then' } \\
\text { (Lyric in 747) }\end{array}$ & Abstraction & Ontological Metaphor & $\begin{array}{l}\text { Container } \\
\text { (Content) }\end{array}$ \\
\hline 24 & $\begin{array}{l}\text { Wenn ich wieder abheb', dann } \\
\text { 'When I take off again, then' } \\
\text { (Lyric in 747) }\end{array}$ & Asymmetry & Ontological Metaphor & $\begin{array}{l}\text { Container } \\
\text { (Surface) }\end{array}$ \\
\hline 25. & $\begin{array}{l}\text { Erst jahrelang nix, auf einmal } \\
\text { lebt der Traum } \\
\text { 'At first nothing for years, } \\
\text { suddenly the dream is alive' } \\
\text { (Lyric in Danke danke) }\end{array}$ & Asymmetry & Orientational Metaphor & $\begin{array}{c}\text { Space } \\
\text { (Front-Back) }\end{array}$ \\
\hline 26. & $\begin{array}{l}\text { That goes out to the first love } \\
\text { 'That goes out to the first } \\
\text { love' } \\
\text { (Lyric in Danke danke) }\end{array}$ & Conventionality & Orientational Metaphor & $\begin{array}{c}\text { Space } \\
\text { (Centre- } \\
\text { Periphery) }\end{array}$ \\
\hline 27. & $\begin{array}{l}\text { Du hautest Pflaster auf dein } \\
\text { Blut } \\
\text { 'You put plasters on your } \\
\text { blood' } \\
\text { (Lyric in Nimmerland) }\end{array}$ & Systematicity & Orientational Metaphor & $\begin{array}{c}\text { Space } \\
(\text { Contact })\end{array}$ \\
\hline 28. & $\begin{array}{l}\text { Weil ich es sonst ab dann } \\
\text { vielleicht einfach nicht mehr } \\
\text { kann } \\
\text { 'Because otherwise I might } \\
\text { not be able to do it anymore' } \\
\text { (Lyric in Nimmerland) }\end{array}$ & Conventionality & Ontological Metaphor & $\begin{array}{l}\text { Scale } \\
\text { (Path) }\end{array}$ \\
\hline
\end{tabular}




\begin{tabular}{|c|c|c|c|c|}
\hline 29. & $\begin{array}{l}\text { Deswegen zog es mich heute } \\
\text { raus aufn Dienstag } \\
\text { 'That's why I was drawn out } \\
\text { today on Tuesday' } \\
\text { (Lyric in Killer) }\end{array}$ & Asymmetry & Orientational Metaphor & $\begin{array}{c}\text { Space } \\
\text { (Near-far) }\end{array}$ \\
\hline 30. & $\begin{array}{l}\text { Paar Texte hin und her in } \\
\text { diesem gottverdammten } \\
\text { Gruppenchat } \\
\text { 'Couple texts back and forth in } \\
\text { this goddamn group chat' } \\
\text { (Lyric in Killer) }\end{array}$ & Abstraction & Orientational Metaphor & $\begin{array}{c}\text { Space } \\
\text { (Up-Down) }\end{array}$ \\
\hline 31. & $\begin{array}{l}\text { Schon steh'n sie unten an der } \\
\text { Tür und klingeln Sturm - los, } \\
\text { runter jetzt! } \\
\text { 'They are already standing } \\
\text { downstairs at the door and } \\
\text { ringing the storm - come on, } \\
\text { get down!' } \\
\text { (Lyric in Killer) }\end{array}$ & Asymmetry & Ontological Metaphor & $\begin{array}{c}\text { Identity } \\
\text { (Superimposition) }\end{array}$ \\
\hline 32. & $\begin{array}{l}\text { Okay, weil ich 'n bisschen } \\
\text { eingerostet bin } \\
\text { 'Okay, because I'm a little } \\
\text { rusty' } \\
\text { (Lyric in Killer) }\end{array}$ & Systematicity & Ontological Metaphor & $\begin{array}{c}\text { Excistence } \\
\text { (Bounded Space) }\end{array}$ \\
\hline 33. & $\begin{array}{l}\text { Häng' ich erstmal an den } \\
\text { Jungs und danach erstmal an } \\
\text { mei'm Gin } \\
\text { 'First I hang on the guys and } \\
\text { then on my gin' } \\
\text { (Lyric in Killer) }\end{array}$ & Conventionality & Ontological Metaphor & $\begin{array}{l}\text { Container } \\
\text { (Content) }\end{array}$ \\
\hline 34. & $\begin{array}{l}\text { Ich hab' Schiss, du bist } \\
\text { Rauschgift } \\
\text { 'I'm scared, you're drug' } \\
\text { (Lyric in Killer) }\end{array}$ & Asymmetry & Orientational Metaphor & $\begin{array}{c}\text { Container } \\
\text { (Full-Empty) }\end{array}$ \\
\hline 35. & $\begin{array}{l}\text { Mein Kopf denkt nicht klar, ey } \\
\text { 'My head doesn't think } \\
\text { clearly, ey' } \\
\text { (Lyric in Killer) }\end{array}$ & Conventionality & Orientational Metaphor & $\begin{array}{c}\text { Space } \\
(\text { Contact })\end{array}$ \\
\hline 36. & $\begin{array}{l}\text { Da schubst mich deine Hüfte } \\
\text { weg, } \\
\text { 'Your hip pushes me away' } \\
\text { (Lyric in Killer) }\end{array}$ & Systematicity & Orientational Metaphor & $\begin{array}{c}\text { Space } \\
\text { (Near-far) }\end{array}$ \\
\hline 37. & $\begin{array}{l}\text { „Ey, ich will tanken!“, sagst } \\
\text { du in mein Ohr } \\
\text { "Hey, I want to fill up!" You } \\
\text { say in my ear' } \\
\text { (Lyric in Killer) }\end{array}$ & Conventionality & Ontological Metaphor & $\begin{array}{c}\text { Container } \\
\text { (Containment) }\end{array}$ \\
\hline 38. & $\begin{array}{l}\text { Und morgens in dei'm } \\
\text { Treppenhaus mit dickem Kopf } \\
\text { und Lächeln } \\
\text { 'And in the morning in the } \\
\text { stairwell with a fat head and } \\
\text { a smile' } \\
\text { (Lyric in Killer) }\end{array}$ & Asymmetry & Ontological Metaphor & $\begin{array}{l}\text { Container } \\
\text { (Surface) }\end{array}$ \\
\hline 39. & $\begin{array}{l}\text { Und immer unter Druck blüh' } \\
\text { ich auf } \\
\text { 'And I always flourish under } \\
\text { pressure' } \\
(\text { Lyric in Genau wie } d u)\end{array}$ & Systematicity & Orientational Metaphor & $\begin{array}{c}\text { Force } \\
\text { (Diversion) }\end{array}$ \\
\hline
\end{tabular}




\begin{tabular}{|c|c|c|c|c|}
\hline 40. & $\begin{array}{l}\text { Wenn ich beim Lachen die Luft } \\
\text { durch die Nase schieb' } \\
\text { 'When I push the air through } \\
\text { my nose while laughing' } \\
\text { (Lyric in Genau wie du) }\end{array}$ & Asymmetry & Ontological Metaphor & $\begin{array}{c}\text { Force } \\
\text { (Compulsion) }\end{array}$ \\
\hline 41. & $\begin{array}{l}\text { Ich such' nach Zeilen in mir } \\
\text { drin, bis alles passt } \\
\text { 'I look for lines inside of me } \\
\text { until everything fits' } \\
(\text { Lyric in Genau wie } d u)\end{array}$ & Abstraction & Ontological Metaphor & $\begin{array}{l}\text { Container } \\
\text { (In-Out) }\end{array}$ \\
\hline 42. & $\begin{array}{l}\text { Die ganze Welt passt in vier } \\
\text { Wände } \\
\text { 'The whole world fits into } \\
\text { four walls' } \\
\text { (Lyric in Chip in) }\end{array}$ & Asymmetry & Ontological Metaphor & $\begin{array}{c}\text { Container } \\
\text { (Full-Empty) }\end{array}$ \\
\hline 43. & $\begin{array}{l}\text { Ich glaub', ich schenk' dir den } \\
\text { Tag } \\
\text { 'I think I'll give you the day' } \\
\text { (Lyric in Chip in) }\end{array}$ & Conventionality, & Ontological Metaphor & $\begin{array}{c}\text { Force } \\
\text { (Attraction) }\end{array}$ \\
\hline 44. & $\begin{array}{l}\text { Ma' angenomm'n, mein Kopf } \\
\text { wär' still und federleicht } \\
\text { 'I suppose my head was still } \\
\text { and light-featherly' } \\
\text { (Lyric in Irgendwann Happy) }\end{array}$ & Abstraction & Ontological Metaphor & $\begin{array}{l}\text { Multiplicity } \\
\text { (Merging) }\end{array}$ \\
\hline 45. & $\begin{array}{l}\text { Und ich käm' mit mir selber } \\
\text { klar, hätt' mein' Schädel frei } \\
\text { 'And I would get along with } \\
\text { myself, would have my skull } \\
\text { free' } \\
\text { (Lyric in Irgendwann Happy) }\end{array}$ & Conventionality & Ontological Metaphor & $\begin{array}{l}\text { Excistence } \\
\text { (Process) }\end{array}$ \\
\hline 46. & $\begin{array}{l}\text { Wenn ich mich endlich } \\
\text { entscheiden könnt', ohne dass } \\
\text { es mich zerreißt } \\
\text { 'When I can finally make up } \\
\text { my mind without it tearing } \\
\text { me apart' } \\
\text { (Lyric in Irgendwann Happy) }\end{array}$ & Conventionality & Ontological Metaphor & $\begin{array}{l}\text { Excistence } \\
\text { (Object) }\end{array}$ \\
\hline 47. & $\begin{array}{l}\text { Und wenn ich immer nur } \\
\text { glücklich wär' ohne grauen } \\
\text { Tag } \\
\text { 'And if I were always happy } \\
\text { without a gray day' } \\
\text { (Lyric in Irgendwann Happy) }\end{array}$ & Abstraction & Ontological Metaphor & $\begin{array}{l}\text { Container } \\
\text { (Content) }\end{array}$ \\
\hline 48. & $\begin{array}{l}\text { Wenn mein Leben ganz grade } \\
\text { verlief', ohne Auf und Ab } \\
\text { 'When my life was just right, } \\
\text { without ups and downs' } \\
\text { (Lyric in Irgendwann Happy) }\end{array}$ & Systematicity & Orientational Metaphor & $\begin{array}{c}\text { Space } \\
\text { (Up-Down) }\end{array}$ \\
\hline 49. & $\begin{array}{l}\text { Ich glaube, Freunde und } \\
\text { Familie sind die Zutat } \\
\text { 'I think friends and family are } \\
\text { the ingredient' } \\
\text { (Lyric in Gerade jetzt) }\end{array}$ & Asymmetry & Ontological Metaphor & $\begin{array}{c}\text { Identity } \\
\text { (Matching) }\end{array}$ \\
\hline 50. & $\begin{array}{l}\text { auch wenn man laut lebt } \\
\text { 'even if you live loudly' } \\
\text { (Lyric in Gerade jetzt) }\end{array}$ & Abstraction & Ontological Metaphor & $\begin{array}{l}\text { Container } \\
\text { (Surface) }\end{array}$ \\
\hline
\end{tabular}




\begin{tabular}{|c|l|c|c|c|}
\hline 51. & $\begin{array}{l}\text { Irgendwas war aufgebraucht } \\
\text { und leer } \\
\text { 'Something was used up and } \\
\text { empty' } \\
\text { (Lyric in Wie früher Mal Dich) }\end{array}$ & Conventionality & Ontological Metaphor & $\begin{array}{l}\text { Container } \\
\text { (Content) }\end{array}$ \\
\hline 52. & $\begin{array}{l}\text { Und es sollt mal laufen, bis wir } \\
\text { alt und grau sind } \\
\text { 'And it should run until we're } \\
\text { old and gray' } \\
\text { (Lyric in Wie früher Mal Dich) }\end{array}$ & Abstraction & Ontological Metaphor & $\begin{array}{l}\text { Container } \\
\text { (Content) }\end{array}$ \\
\hline
\end{tabular}

Based on table 2 it can be seen that there are 52 Mark Forster's song lyrics which contain metaphorical expressions in the Liebe $S / W$ album. Based on Saeed's (2009) metaphorical characteristics theory, it is found that there are 13 data in the form of song lyrics with abstraction characteristics, 15 data with conventional characteristics, 9 data with systematic characteristics, and 15 data with asymmetric characteristics. Through Lakoff \& Johnson's (2003) conceptual metaphor theory, there are 32 data which are song lyrics in the form of ontological conceptual metaphors, 15 data in the form of orientational conceptual metaphors, and 5 data in the form of structural conceptual metaphors. In Mark Forster's song lyrics, various image schemes are also found based on the Croft \& Cruse theory (2004). The results show that there are 20 data in the form of song lyrics with a container image scheme, 4 data with the Unity/Multiplicity image scheme, 4 data with the existence image scheme , 5 data with an identity image scheme, 12 data with a space image scheme and 1 data with a scale image scheme.

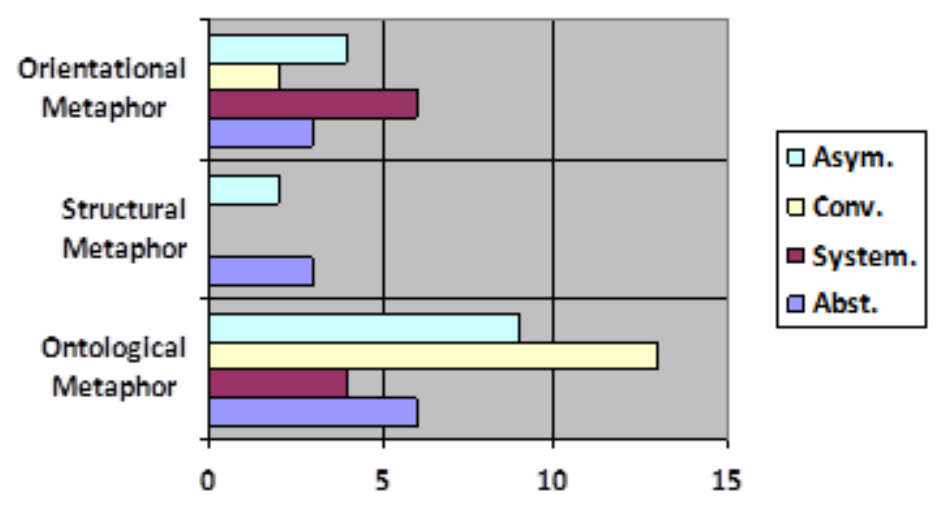

Figure 2. Metaphorical Characteristics And Conceptual Metaphor in The Liebe $S / W$

Album

Based on Figure 2, it can be seen that in the lyrics of Mark Forster's song on the album Liebe $S / W$ contains many ontological conceptual metaphors with the characteristics of conventional metaphors. There are 32 ontological conceptual metaphors contained in the song lyrics with 13 characteristics of conventional metaphors, 9 asymmetries, 6 abstractions and 4 systematic. The lyrics of Mark Forster's song in his album also contain 15 orientational metaphors with the characteristics of 6 systematic metaphors, 4 asymmetries, 3 abstracts and 2 conventional metaphors. There is also 5 structural conceptual metaphors in Mark Forster's song lyrics in Liebe $S / W$ album with 3 abstraction characteristics and 2 asymmetrical characteristics. 
Tabel 3. Relationship between metaphorical theories in Liebe $S / W$ album

\begin{tabular}{|c|c|c|c|}
\hline No. & $\begin{array}{c}\text { Metaphorical } \\
\text { Characteristic Theory } \\
\text { by Saeed (2009) }\end{array}$ & $\begin{array}{l}\text { Conceptual Metaphor Theory (CMT) } \\
\text { by George Lakoff and Mark Johnson } \\
(\mathbf{2 0 0 3 )}\end{array}$ & $\begin{array}{c}\text { Image Schema Theory } \\
\text { by Croft \& Cruse } \\
(\mathbf{2 0 0 4 )}\end{array}$ \\
\hline 1. & Abstraction & $\begin{array}{l}\text { Ontological Metaphor, Orientational } \\
\text { Metaphor and Structural Metaphor }\end{array}$ & $\begin{array}{l}\text { Container (in-out, } \\
\text { content and surface ), } \\
\text { Multiplicity (link and } \\
\text { merging), Identity } \\
\text { (matching), Space } \\
\text { (centre-periphery and } \\
\text { up-down) and Excistence } \\
\text { (process) }\end{array}$ \\
\hline 2. & Asymmetry & $\begin{array}{l}\text { Ontological Metaphor, Orientational } \\
\text { Metaphor and Structural Metaphor }\end{array}$ & $\begin{array}{l}\text { Force (compulsion), } \\
\text { Container (surface, } \\
\text { containment, in-out and } \\
\text { full-empty), Space } \\
\text { (contact, front-back and } \\
\text { near-far) and Identity } \\
\text { (superimposition and } \\
\text { matching) }\end{array}$ \\
\hline 3. & Conventionality & Ontological Metaphor & $\begin{array}{l}\text { Force (blockage, } \\
\text { attraction and restraint), } \\
\text { Container (content and } \\
\text { containment), Space } \\
\text { (centre-periphery, } \\
\text { contact), Scale (path), } \\
\text { Excistence (process and } \\
\text { bbject) }\end{array}$ \\
\hline 4. & Systematicity & $\begin{array}{l}\text { Ontological Metaphor and Orientational } \\
\text { Metaphor }\end{array}$ & $\begin{array}{l}\text { Space (up-down, centre- } \\
\text { periphery, contact, near- } \\
\text { far and up-down), } \\
\text { Multiplicity (collection), } \\
\text { Excistence (bounded } \\
\text { space) and Force } \\
\text { (attraction, diversion) }\end{array}$ \\
\hline
\end{tabular}

Based on table 3 , it is found a relationship between metaphorical characteristic theory by Saeed (2009), conceptual metaphor theory by George Lakoff and Mark Johnson (2003), and Image Schema Theory by Croft \& Cruse (2004) in the lyrics of Mark Forster's song in the album Liebe $S / W$. Data with the characteristics of abstraction and asymmetry contain the conceptual expression of structural, ontological and orientational conceptual metaphors. Data with conventional characteristics only contain the conceptual metaphor expression of the ontology. The ontology and orientational conceptual metaphors are contained in the data with the characteristics of systematic. The ontological conceptual metaphor in the lyrics of Mark Forster's song in the Liebe $S / W$ album reflects the image scheme of force, container, multiplicity, identity, scale and excistence. The orientational conceptual metaphor contains the image schema of force, container, and scale. Data in the form of structural conceptual metaphors reflect the image scheme in the form of excistence, multiplicity, identity and container. 


\section{Conclusion}

After analyzing the types of metaphors found in Mark Forster's song lyrics in the Liebe $S / W$ album, it can be concluded that Mark Forster's songs on that album tell about the life of him. From the song lyrics, there were 52 data containing metaphorical expressions. Based on the results of the analysis in accordance with Saeed's theory (2009) as a metaphorical characteristics theory, it shows that there are 13 data in the form of song lyrics with abstraction characteristics, 15 data with conventional characteristics, 9 data with systematic characteristics, and 15 data with asymmetric characteristics.

Furthermore, data analysis using the Lakoff \& Johnson theory shows that the conceptual metaphors are found as many as 32 ontological metaphors, 15 orientational metaphors, and 5 structural metaphors. The image schemes found are 20 container schemes, 4 unity schemes, 4 existence schemes, 5 identity schemes, 12 space schemes and 1 data with a scale image scheme. The most type of conceptual metaphor found in the song lyrics in the Liebe $S / W$ album is the ontological conceptual metaphor. The ontological metaphors in the album allow us to conceptualize and contain things, experiences and processes, but they are still unclear or abstract as if they have definite physical properties. The ontological metaphors in the album make us handle things rationally based on Mark Forster's experience. The many uses of this ontological metaphor indicate that the message of the songs contained in the Liebe $S / W$ album was also not conveyed explicitly by the songwriters. The songwriters convey messages from the songs on the album through borrowing physical concepts for abstract concepts to make them more attractive to listeners.

In addition, a pattern was found based on the metaphorical theory of Saaed, Lakoff \& Johnson, and Croft \& Cruse on the lyrics of Mark Forster's song on the album Liebe S/W. The patterns found are 1) metaphors that have the characteristics of abstraction and asymmetry into the types of ontological, orientational and structural conceptual metaphors with image schemes in the form of force, container, multiplicity, identity, scale and excistence. 2) Metaphors that have conventional characteristics into the ontological conceptual metaphor type with image force, container, space, scale and excistence schemes. 3) metaphors that have systematic characteristics into the type of ontological conceptual metaphors and orientation with image space, multiplicity,excistence and force scheme.

\section{References}

Aceng Ruhendi Saifullah. (2018). Semantik Dan Dinamika Pergulatan Makna, Jakarta: Bumi Aksara.

Baiq Haula \& Tajudin Nur. (2018). Konseptualisasi Metafora dalam Rubrik Opini Kompas Tahun 2018: Kajian Semantik Kognitif“, Jurnal Mozaik Humaniora, pp. 149-156, Volume 18, No. 2.

Djohan. (2016). Psikologi Musik, Yogyakarta: Indonesia Cerdas.

Dudenredaktion. (2011). Duden dictionary - Das große Wörterbuch der deutschen Sprache, Berlin: Der Duden Verlag.

Duden - Das große Wörterbuch der deutschen Sprache [Online], available: https://www.duden.de/woerterbuch.

George Lakoff and Mark Johnson. (2003). Methaphors We Live By, Chicago: The University of Chicago Press.

Jhon I Saeed. (2009). Semantics, Australia: West Sussex, Wiley \& Sons. 
M. B. Miles, A. M. Huberman \& Saldana. (2014). Qualitative Data Analysis: A Method of Source Book, London: Sage Publication.

Mark Forster, Liebe S/W. (2019). [Album]. Berlin: Marecs.

Moradi, N., Jabbari, M. J. (2020). A Study of Rendering Metaphors in the Translation of the Titles of Persian Medical Articles. Budapest International Research and Criticsin Linguistics and Education (BirLE) Journal, 540-551.

Noie, S. (2018). An Investigation of Mystic Term on "Conference of The Birds" of

Attar on The Basis of Van Doorslaer's Map. Budapest International Research and Critics in Linguistics and Education (BirLE) Journal, 1-10.

Oxford Dictionary [Online], Available: https://www.oxfordlearnersdictionaries.com/definition/english/

Pons German dictionary [Online], available: https://de.pons.com/.

Sathyaraj Venkatesan \& Sweetha Saji. (2020). Reflections on the Visceral: Metaphors and Illness Experience“, Rupkatha Journal on Interdisciplinary Studies in Humanities, pp. 1-11, Vol. 12, No. 1, Januari-Maret.

Sudaryanto. (2015). Metode dan Aneka Teknik Analisis Bahasa: Pengantar Penelitian Wahana Kebudayaan secara Linguistis, Yogyakarta: Duta Wacana University Press.

Tryta Dessiliona \& T. Nur. (2018). Metafora Konseptual Dalam Lirik Lagu Band Revolverheld Album In Farbe“, Jurnal Sawerigading, pp. 177-184, Volume 24 No. 2, Desember.

W. Croft \& D. A. Cruse. (2004). Cognitive linguistics, Cambridge: Cambridge University Press. 